\title{
Customer Relationship Management (CRM) in Banking Sector in Albania
}

\author{
Ph.D Cand. Aurela Ramaj \\ University of Vlora "Ismail Qemali", Albania \\ Faculty of Economy \\ aurelabifsha@yahoo.ca
}

\begin{abstract}
The aim of this paper is to examine the Customer Relationship Management as a new methodology looks forward to identify and attract consumers through the process of developing relationships (business - customer). The methodology of the CRM aims to maintain customer satisfaction and increase consumer loyalty. The purpose of this paper is to know the basic capabilities of CRM systems and in-depth knowledge of methods and management techniques customer relationships. This paper will examine the methods and techniques of customer relationship management and display functionalities customer relationship management-implemented in banks.
\end{abstract}

Keywords : customer relationships management, customer satisfaction, customer loyalty, data, information, banks.

\section{Customer Relationship Management CRM}

One of the main tasks of the department promotion and advertising of bank is to bring together buyers and sellers of products and services to create clients. At the time when the philosophy of all enterprises can not only be customer-oriented, development and maintenance long-term relations of cooperation and engagement of a company with customers is extremely difficult but very important for the development of each business. The customer relationship management (CRM) has become a necessary strategy for all firms, since effective implementation may increase satisfaction, loyalty and customer retention and thus, sales and lead to repetitive purchases (Feinberg \& Kadam 2002, Kotorov 2002, Anton \& Hoeck 2002). However, although the CRM is one of the fastest growing administrative approaches to the modern enterprise, the application has not always yield the expected results (Rigby et al., 2002). In a survey of the Kekoe (2002) found that up to $20 \%$ of senior business officials argued that CRM initiatives had hurt customer relationships. Consequently, firms in the banking sector should consider carefully investment in customer relationship management (CRM) in order to have the desired business results.

A review of the literature shows that there are a variety of definitions for the Customer Relationship Management. One reason that could explain this diversity of definitions is the diversity that can be offered to any company adopting such a system, development and management of relationships with customers. The simplest definition can be given for the CRM according to Zikmund et al. (2003) is: "The CRM is a process whose aim is to collect information to assist the administrative staff of a company to manage the best possible relations with its customers. "The Kalakota \& Robinson (2001) report that the 'CRM is a comprehensive sales process, marketing, and strategy services depends on broad scale concerted action by a company to attract and customer retention. "Additionally the Tiwana (2001) mentions that the 'CRM is a combination business processes and technology that takes a business and seeks to decode the behavior of customers in order to differentiate their products and services aiming at obtaining competitive advantage. "The CRM uses the Information and Communication Technologies to incorporate practical marketing, sales and service, and to provide services tailored to the needs of each customer in order to strengthen the consumer's loyalty and increase profits.

A customer-centric management system consists of two main parts:

- $\quad$ Analysis of customer data

- $\quad$ Proposed modalities 
More specifically, the CRM is the strategic development of the company, which is using the database features and technology, formulate a comprehensive view of their customers to ensure that all operational procedures are followed to improve the bank's relationships with its customers. In other words, CRM, as is clear from the above definitions, is a set of procedures designed to collect and analyze information to assist a company in formulating and evaluating alternative strategic plans. The purpose of CRM is to improve the services offered by a company to its customers, enhance customer satisfaction and contribute to maintaining long-term relationships. An effective CRM system contains details of all customers of the bank to ensure that all parts of the bank to be able to access them reason to combine the needs of customers with the products and be observed throughout the history of customer orders. Especially a bank CRM system should be able to give information about the services offered by the call center and gives a detailed report in relation to the movements of a customer or a company just after the completion of the transactions.

\subsection{CRM and Consumer Satisfaction}

In a constantly changing environment in which the needs and expectations of changing consumer and tend to seek perfect products and services with 10 highest standards, companies probably can not provide this "perfection". The philosophy of customer satisfaction based on:

- $\quad$ the recognition of consumers (hence the careful segmentation of the market)
finally $\quad$ to determine the needs and expectations (the needs and expectations of each specific market segment) and

in measuring their conceptions.

The knowledge of the needs of consumers is particularly important since it is the target of business to meet these needs. In this way it is easier to accelerate procedures for providing the ideal products and services to consumers. Another problem seems to be facing businesses seems to be the inability to find other methods that make consumers satisfied. The contact of workers in business with customers can provide answers to this problem. Officials first line of contact they have with their clients of the firm can understand their needs and to transfer the management of the firm. This relationship staff - customer feels its customers that the company cares about their needs and their problems (Chase \& Garvin 1989, Stonebraker \& Leon, 1994).

\section{$1.2 \quad$ CRM and customer loyalty}

Sometimes assessment of the degree of customer satisfaction is not reliable indicator for the performance or quality level of the company, particularly in terms of strong competition such as the banking sector in review.

So while many organizations focused on satisfying their consumer reach and maintain consumer loyalty is the ultimate objective specifically service businesses. Loyal customers buy more, are willing to spend more, it is easier to approach their business and behave like enthusiastic advocates for business. Satisfaction is a key condition for the dedication of a set of customers, but not a sufficient condition. The term "consumer loyalty" describes the tendency of customers to choosing a particular business or product over others for a particular service. For packaged goods industry customers can be described as loyal to brand (brand loyalty). Consumer loyalty is generally, based on services, adhering favorite of the same supplier, that based on either the dedication or in actual limitations. The consumer satisfaction and willingness to repurchase the product / service are positively correlated. The Reichheld \& Sasser (1990) and Reichheld (1996) studied the value of existence consumer loyalty from customer complaints, from anticipating change consumer behavior and the full understanding of why consumers turn to competitors. Consumers remain loyal because of the value they receive from the company. Maintaining the customer requires a continuous and living relationship with the customer.

Customers who do not have problems on offered services, have the highest levels of loyalty. However, their willingness to pay more is not significantly higher than customers who have problems in the services but solved satisfactorily. Thus, companies wishing to improve their services, especially above the desired level, they can do calculating certain cost. 
The resulting problem is that the intention of the consumer to purchase may not eventually lead to purchase and even the repeated purchases are not sure that they reflect the intention to purchase.

\subsection{Designing of CRM System}

Generally, the implementation of CRM system based on important information relating to clients and aim to Creating a database with information on the company's clientele. The significance of the existence of this base is not just storage data for customers but is the first step for subsequent use for the purposes of the bank.

Generally, according to Ahn et al. (2003) points on which the firm must focus those relates to practical issues around the effective implementation and management of CRM is:

1. Data collection: To collect the data of the customers bank should first determine what are the elements that wishes to withdraw from their customers. Once identifies what exactly information needs, then with internet applications, may be made collection of data in the customer relationship management program.

2. Pre-processing of data: Refers to all the steps taken before data analysis begins. This step involves many procedures such as identification of transactions and completing transactions. This is a lengthy process, in which many processes are automated.

3. Data analysis: The purpose of data analysis is to extract those information necessary to ensure efficient service to customers. In many cases, however, the number of collected data is very large and in these cases there are several data analysis techniques.

4. Interaction system with user and customization: designing of the system that connects the customer with the bank is a particularly critical point for the success of (CRM) system. The most important factor for success of the system is to understand the bank who are the users of the system and what they expect from the system ( the Cooley 2000).

5. Knowledge base: The main function of CRM is understanding and practical use of customer information. The way in which the information that customers send, is stored, increased and organized will determine ultimately and the effectiveness of services offered to client.

6. Personalized Services: in today's competitive environment, provide value to the customer is a particularly important element for service businesses. The way in which value offered to customer is through in-depth knowledge of and personalization servicing.

7. $\quad$ ASP (application service provider): Another important element in CRM design is the selection of the ASP. The ASP hosts and manages software and provides the service to the customer via the Internet or private leased telecommunication lines. In recent years, a shift to the ASP's for CRM solutions, especially by the firms that non have the expertise and technology to support integrated customer relationship management systems. Important benefits resulting from the use of ASP is the lowest cost, faster implementation, increased functionality and reliability of the provider.

\subsection{Benefits of implementing CRM in the banking sector.}

The society of information creates an ever-changing environment for banks, which should be vigilant and adopt new developments in sector in order to remain competitive. The basic difference in the way functioning of banks today is in the fact that more and more transactions made electronically, a totally different philosophy of customer service than its physical presence in a store of bank. The traditional customer service models have now saturated and the development and profitability of banks now relies on new opportunities provided by developments in technology. Competition and function in the new business environment opens up a large part of strategies and options opportunities for innovative products and services.

The function on a such business environment has reported significant benefits for banks, such as: 
1. Reduce operating costs.

2. Improve service levels

3. Low barriers to entry in the banking market

2. Implementation and Application of CRM System in the banking sector

\subsection{Stages of implementation CRM system}

The design and implementation of a CRM should start by identifying business objectives, goals and needs, and how will happens the change of nature of the company in customer-centric.

Thus we have the following implementation stages:

1. Identify business goals and objectives

2. Make customer-centric business strategy

3. Design CRM system

4. Select the appropriate infrastructure

5. Implementation

\subsection{Results of CRM implementation}

Customer Relationship Management (CRM) offers features and functions on the following areas of business:

Department of Marketing - Improves the effectiveness of marketing activities offering functionality for marketing planning, campaign management, lead management, marketing analytics, customer segmentation (market segmentation), personalization (personalized communication) and trade promotion management.

Sales department - Optimizes all sales channels with functions sales planning and sales forecasting, customer management by geographical area, monitoring activities and potential opportunities and control of cost estimates of contracts, incentives and sales commissions.

Service - Utilizes the potential of profitability for the organization of services with functionality for multi-channel services, management and use of resource, management of maintenance functions, organization and provision of services, customer care and professional services.

Analytics - Evaluates business performance with ample opportunity analysis covering information relating to clients in marketing, sales, services and performance of sales and communication channels.

E-commerce - Converts the internet on a profitable sales channel with functionality for marketing, sales, services and online analytical reports.

Interaction center operations and management - Improves performance of telephone customer service center (interaction center) with functions for telemarketing, telesales and additional features that focus to the client.

Channel management - Optimizes the sales channels through representatives (Partner) with functionality for partner management, network marketing partners, sales, marketing services through a network of partners. 


\title{
3. $\quad$ Research results
}

I received completed questionnaires from forty (40) permanent and seasonal employees aged from 20 years to 55 years. Of 40 respondents, more than half were graduates Higher Educational Institutions and Technological Educational Institutes, while all officials have attended seminars during their work.

Educational level of Bank employees

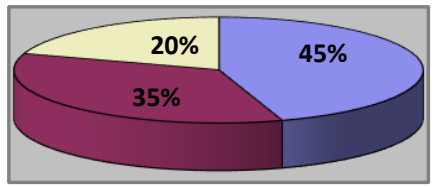

\author{
口Higher educational \\ institutions \\ Technological education \\ institutes \\ 口High school education
}

Figure 1. Presentation of educational level of Bank employees

According to the results of the questionnaire almost all employees consider the CRM system needed to improve the service customers and those who use it every day seem perfectly satisfied with the possibilities offered by the new platform customer service.

Age of the bank employees

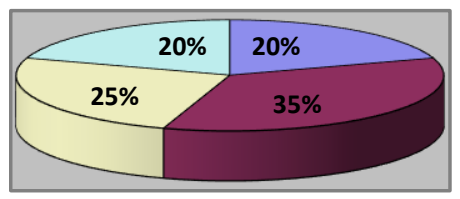

\begin{tabular}{|l|}
\hline $20-25$ \\
$\square 26-35$ \\
$\square 36-49$ \\
$\square 50$ and over
\end{tabular}

Figure 2. Presentation of the age of the bank employees

Satisfaction of employees using the system CRM 


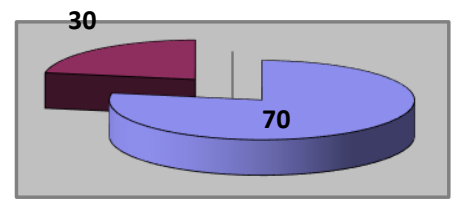

\section{$\square$ satisfied \\ $\square$ dissatisfied}

Figure 3. Satisfaction of employees using the system CRM

Of course there are officials who do not know how to use or not need to use the CRM system. Such employees are on the most, employees in the funds of the branches, since these CASH transactions made through the old system.

CRM use frequency by employees

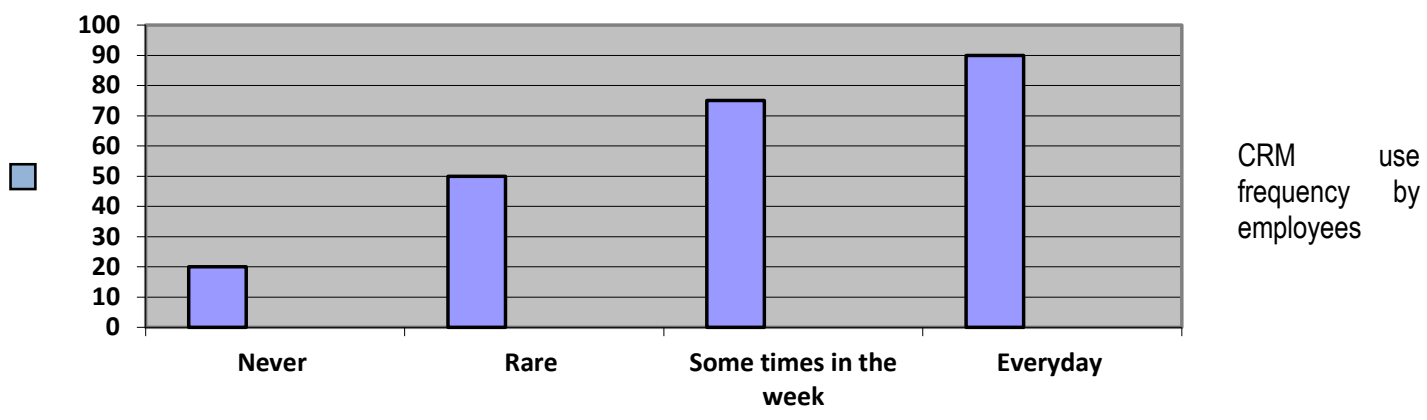

Figure 4. Presentation of CRM use frequency by employees

It should be noted that the more young age are officials, more easily find the transition from one system to another. For those yet use the CRM system, the transition was possible without presenting big problems. Employees who use this system characterize useful tool and reliable means for serving customers. In addition all employees who use on a daily basis CRM system support that helps in understanding the needs of customers.

Particularly important element is that all of the respondents consider that the customer needs and problems faced in relation to the bank don't records adequate as well as the fact that $100 \%$ of respondents consider that the information provided by their customers could be used effectively. The efficient management of information provided by the customer is a key point of a customer relationship management system, which demonstrates that the same bank employees consider it imperative to implement CRM system. Finally, we observe that the majority of workers comes either in a direct or indirect contact with customers. 


\section{Conclusions}

We conclude that the implementation and operation of a CRM system by the Bank is particularly important. Through this facilitated both, management as well as cooperation between the departments of the bank to better serve of customers through the effective registration of their characteristics and needs. The use of a CRM system will contribute significantly to increasing the degree customer satisfaction by the Bank. The most important conclusion, however, has to do with the specific characteristics that is good to have a CRM system in order to achieve the objectives. Such a system therefore should be able to use large amounts of data on their customers, to allow their classification based on the characteristics, needs and / or their behavior, so that the bank can to develop different strategies for each category.

These strategies are relevant to the promotion of new goods, their service, approving loans, informing them through appropriate communication channels, etc. Of course, should this data be refreshed and updated at regular intervals to enable the recording of customer profile and its evolution through time. It is evident that in order to allow such volume management and such data, is necessary to first implement a Analytical CRM type with the presence of a Data Warehouse (DWH) which will record all the required dynamic data.

At the same time, the development of the database will enable, with the aid of a Analytical CRM tool, the use of data in order to feed the marketing for new product design and analysis (and not only for existing customers) with statistical methods such as segmentation, cluster analysis etc., The collections for the use of credit scoring as well as consumerbusiness-mortgage lending in the form of reporting for analysis and monitoring of all clients.

\section{References}

[1] Feinberg, R., and Kadam, R. (2002). e-CRM web service attributes as determinants of customer satisfaction with retail Web sites, International Journal of Service Industry Management, 13 (5), 432 - 451

[2] Chase, Richard B. and Garvin, David A. (1989), "The Service Factory", Harvard Business Review,Jul-Aug, 1989, Vol. 67, No. 4, 61-69.

[3] Kalakota, R. \& Robinson, M. (2001) e-Business 2.0: Roadmap for Success (Pearson Education Corporate Sales Division).

[4] Anderson E., Fornell C., Lehmann D., : "Customer Satisfaction, Market Share and Profitability: Findings from Sweden"Journal of Marketing

[5] Ernst \& Young (1999) E-commerce: Customer Relationship Management. Special Report Technology in Financial Services, Ernst \& Young, New York.

[6] Kekoe, L. (2002). Long live e-business: software is finding a new role in helping companies to share information effectively", Financial Times, March 16, 14

[7] Anderson, Eugene W. and Mittal, Vikas. (2000), "Strengthening the Satisfaction- Profit Chain", Journal of Service Research, Nov, 2000, Vol. 3, No. 2, 107-120.

[8] Anton, J., and Hoeck, M. (2002). ebusiness Customer Service, The Anton Press: Santa Monica, CA

[9] Heskett, James L., Jones, Thomas O., Loveman, Gary W., Sasser, W. Earl Jr. and

[10] Schlesinger, Leonard A. (1994), "Putting the Service-Profit Chain to Work", Harvard Business Review, Mar-Apr, 1994, Vol. 72, No. 2, 164-174.

[11] Kotorov, R. (2002). Ubiquitous organisational design for e-CRM, Business Process Management Journal, 8 (3), 218 $-232$

[12] Oliver and DeSarbo,(1988) Response determinantsin satisfaction judgments, Journal of Consumer research,14,495507

[13] Rigby, D., Reichheld, E., Schefter, P. (2002). Avoiding the four perils of CRM,Harvard Business Review, 80 (2), 101 $-109$ 
[14] Wirtz J., Bateson J. (1999): "Consumer Satisfaction with Services: Integrating the Environment Perspective in Services Marketing into the traditional Disconfirmation Paradigm", Journal of Business Research, Volume 44, 55-66

[15] Tiwana, A. (2001) The Essential Guide to Knowledge Management: E-Business and CRM Applications (Prentice Hall PTR).

[16] Roberts, M. (1997). Expanding the Role of the Direct Marketing Database. Journal of Direct Marketing 11: 26-35.

[17] Izakovič, L. Application of new information and communication technologies in marketing.

[18] Foster, J, D. (1997). Maintaining Customer Relationships Through Effective Database Marketing: A Perspective for Small Retailers. Journal of Marketing Theory and Practice 5: 31-42.

[19] Gerson, R.F (2001). Secrets of CRM success. Crm2Day.com.

[20] Gordon, I.(1998). Relationship Marketing. John Wiley and Sons Canada Ltd. ISBN 0-471-64173-1

[21] Harte \& Hanks, (2001).Maximizing data value with Customer data Management. Harte \&Hanks inc. 